\title{
Method Validation for Assay of Loperamide Hydrochloride by HPLC in Loperamide Hydrochloride Tablets
}

\author{
Homayun Kabir ${ }^{1 *}$, Ratan Kumar Paul ${ }^{1}$, Md. Saifur Rahaman ${ }^{2}$, Md. Faruak Ahmad ${ }^{1}$, \\ Debu Kumar Bhattacharjya ${ }^{3}$, Md. Samsur Rahaman ${ }^{4}$ \\ ${ }^{1}$ Department of Chemistry, Pabna University of Science and Technology, Bangladesh \\ ${ }^{2}$ Atomic Energy Research Establishment, Bangladesh Atomic Energy Commission, Bangladesh \\ ${ }^{3}$ Department of Biochemistry, Sher-e-Bangla Agricultural University, Dhaka, Bangladesh \\ ${ }^{4}$ Department of Applied Chemistry, Islamic University, Kushtia-Jhenaidah -7003, Bangladesh
}

\begin{abstract}
A simple, selective, linear, specific, precise and accurate High Performance Liquid Chromatography (HPLC) method was developed and validated for rapid assay of Loperamide Hydrochloride in finished product. Isocratic elution at a flow rate of $1.5 \mathrm{ml} / \mathrm{min}$ was employed on an Inertsil-ODS $3 \mathrm{~V}, \mathrm{Cl}, 100 \times 4.6 \mathrm{~mm}$, $5 \mu$ column. The UV detection wavelength was $224 \mathrm{~nm}$. The mobile phase consisted of acetonitrile: buffer: $1 \mathrm{M}$ $\mathrm{NaOH}=390: 610:$ 0.5.The method was validated in terms of linearity, specificity, accuracy, precision and robustness study. The method was validated as per the International Conference on Harmonization (ICH) guidelines. The method was successfully applied to the analysis of pharmaceutical formulation containing Loperamide Hydrochloride with excellent recovery.
\end{abstract}

Keywords: Loperamide Hydrochloride, RP-HPLC, Accuracy, Precision, Linearity, Robustness.

\section{INTRODUCTION}

Loperamide Hydrochloride (4-( $p$-chlorophenyl)-4-hydroxy- $N, N$-dimethyl-diphenyl-1-piperidine bytyramide monhydrochloride) is a white powder which is slightly soluble in water, freely soluble in alcohol and in methanol. Its chemical formula is $\mathrm{C}_{29} \mathrm{H}_{34} \mathrm{Cl}_{2} \mathrm{~N}_{2} \mathrm{O}_{2}$. It is a piperidine derivative [1] as well is a drug that reduces intestinal mobility and thus widely used for the control and symptomatic relief of diarrhea [2-5]. Moreover, it has been reported that Loperamide Hydrochloride could have some interest as an ant-ihyperalgesic agent reducing pain without causing any side effect on central nervous system [6].

Since 1970, the manufacture and quality assurance of pharmaceutical products have influenced by the demand of process validation because of customers are more concerned about product safety, efficacy and potency [7]. Balan, P. et al, developed a chromatographic separation that was conducted on a Hypersil C18 (150 $\left.{ }^{\circ} \mathrm{A}-4.6 \mathrm{~mm}\right), 5^{\circ} \mathrm{A} \mu$ column from Shimadzu in isocratic mode with mobile phase maintained at $\mathrm{pH} 3.0$ and consisting of potassium dihydrogen phosphate, dipotassium hydrogen phosphate buffer and acetonitrile [8]. The flow rate was $1.0 \mathrm{~mL} / \mathrm{min}$ and effluent was monitored at $210 \mathrm{~nm}$. The retention time was $3.140 \mathrm{~min}$. The method was found to be linear in the range of 10-60 ${ }^{\circ} \mathrm{A} \mu \mathrm{g} / \mathrm{mL}$ with correlation coefficient of 0.9992 . The method was validated over the range of $80-120$ $\mu \mathrm{g} / \mathrm{mL}$ and is accurate and precise. M. Madhu et al., developed a validated Reverse Phase High Performance Liquid Chromatography (RP-HPLC) method for the determination of Loperamide Hydrochloride in bulk and pharmaceutical formulation [9]. The chromatographic elution was performed on a Luna C8 $(4.6 \times 150 \mathrm{~mm})$ with $5 \mu \mathrm{m}$ particle size using 45:55 v/v solution of acetonitrile and buffer (Buffer is made by mixing $3.0 \mathrm{~g}$ of triethylamine hydrochloride and $1.0 \mathrm{~mL}$ of phosphoric acid into 1L distilled water) as a mobile phase and the detection was carried out at 214 $\mathrm{nm}$. The method was found to be linear. The correlation coefficient for Loperamide Hydrochloride was found to be 1.00. Accuracy of the method was assessed by recovery studies and the percentage of recovery was found to be within the range of $25-125 \%$. K. Poornima and K.P. Channabasavaraj estimated Loperamide Hydrochloride and tinidazole simultaneously in bulk and pharmaceutical formulations by Reverse Phase High Performance Liquid Chromatography (RP-HPLC) [10]. The separation was achieved by using Lithosphere RP C-18, $(250 \times 4.6 \mathrm{~mm}, 5 \mu \mathrm{m})$ end capped column 
with a mobile phase containing sodium-1-octane sulfonate buffer, methanol and acetonitrile (sulfonate buffer : methanol : acetonitrile 40: 30: $30 \% \mathrm{v} / \mathrm{v} / \mathrm{v}$ ) where $\mathrm{pH}$ was adjusted to 4.0 (using dilute orthophosphoric acid). The flow rate was $1.0 \mathrm{~mL} / \mathrm{min}$. and column effluent was monitored at $224 \mathrm{~nm}$. Tinidazole and Loperamide Hydrochloride were eluted at about 3.1 and 5.4 minute respectively, indicating the shorter analysis time. The method was found to be accurate, precise and reproducible. The linearity was established in the concentration range of $10-50 \mu \mathrm{g} / \mathrm{mL}$. Limit of Detection (LOD) and Limit of Qualification (LOQ) was found to be $0.001 \mu \mathrm{g} / \mathrm{mL}$ and $0.003 \mu \mathrm{g} / \mathrm{mL}$ for Loperamide Hydrochloride and $0.01 \mu \mathrm{g} / \mathrm{mL}$ and $0.03 \mu \mathrm{g} / \mathrm{ml}$ for tinidazole respectively. Ivana M. Savic et.al. developed a RP-HPLC method for the determination of Loperamide Hydrochloride in the presence of its acid degradation products [11]. Separation of Loperamide from degradation products was performed using zorbax Eclipsed XDB C-18, column with a mobile phase consisting of $0.1 \%$ sodium-octansulphonate, $0.05 \%$ triethylamine, $0.1 \%$ ammonium hydroxide in water: acetonitrile (45:55 v/v) solution. The mobile phase was adjusted to $\mathrm{pH} 3.2$ with phosphoric acid. The method showed high sensitivity with good linearity over the concentration range of $10-100 \mu \mathrm{g} / \mathrm{mL}$.

The present work aimed to develop and validate a new HPLC feasible, sensitive, linear, precise accurate and specific analytical procedure, suitable for application in drug quality control or regulatory laboratory analysis of Loperamide Hydrochloride. The developed analytical method was validated as per International Conference on Harmonization guidelines [12]. The method was validated in terms of linearity, specificity, accuracy, and precision and robustness study. The developed method was successfully applied to the analysis of pharmaceutical formulation containing Loperamide Hydrochloride with excellent recovery.

\section{MAterials AND Methods}

\subsection{Materials, Reagents and Instrumination}

Reference standard of Loperamide Hydrochloride was used from USP reference standard. Loperamide tablets were collect from local market. Each tablet contained $2 \mathrm{mg}$ of Loperamide Hydrochloride. The chemical structure of Loperamide Hydrochloride is shown in figure 1.

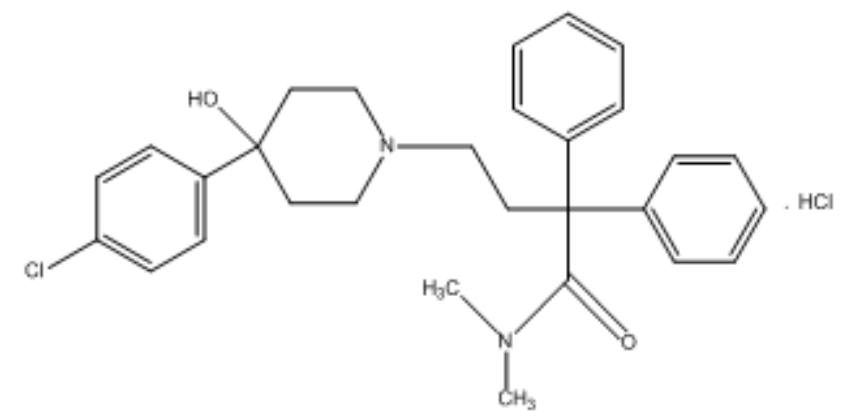

Figure1. Chemical structure of Loperamide Hydrochloride

All chemicals used were of analytical grade. Sodium-1-octansulphonate, sodium hydroxide and acetonitrile for HPLC were obtained from Merck, Germany.

\subsubsection{HPLC System}

The initial chromatographic development were performed in HPLC system (Shimadzu: LC-10AS) at Training Institute for Chemical Industries (TICI), Polash, Narsingdi, Dhaka, Bangladesh. InertsilODS $3 \mathrm{~V}, \mathrm{C} 18,100 \times 4.6 \mathrm{~mm}, 5 \mu$ column was used for isocratic separation.

\subsubsection{Mobile Phase}

Acetonitrile: sodium-1-octane sulfonate buffer: 1M sodium hydroxide (390:610:0.5 \% v/v) with $\mathrm{pH}$ adjusted to 4.0 (adjusted with dilute orthophosphoric acid).

\subsubsection{Detection Wavelength}

The spectrum of $10 \mathrm{ppm}$ solution was recorded separately on UV-Visible spectrophotometer. The peak of maximum absorbance wavelength was observed. The spectra of the substance were showed maximum absorbance at $224 \mathrm{~nm}$.

Flow Rate: $1.5 \mathrm{~mL} / \mathrm{min}$. 


\subsection{Preparation of Working Standard and Sample Solutions of Loperamide Hydrocholride}

\subsubsection{Standard Preparation}

Accurately weighed $10 \mathrm{mg}$ of Loperamide Hydrochloride was dissolved in required amount of mobile phase to prepare about $50 \%, 80 \%, 100 \%, 120 \%$ and $150 \%$ (ranging from $0.1-0.3 \mu \mathrm{g} / \mathrm{mL}$ ) concentration solutions.

\subsubsection{Sample Preparation}

Twenty tablets that contain Loperamide Hydrochloride were weighed and crushed to a fine, homogeneous powder. A quantity equivalent to $10 \mathrm{mg}$ was weighed and diluted with mobile phase to prepare about $50 \%, 80 \%, 100 \%, 120 \%$ and $150 \%$ (ranging from $0.1-0.3 \mu \mathrm{g} / \mathrm{mL}$ ) concentration solutions.

\subsection{Optimization of Chromatographic Conditions}

The method was carried out on trial and error basis and the best resolution was obtained at mobile phase concentration of acetonitrile: sodium-1-octane sulfonate buffer: $1 \mathrm{M}$ sodium hydroxide $=390: 610: 0.5 \% \mathrm{v} / \mathrm{v}$; where the $\mathrm{pH}$ of mobile phase was adjusted to 4.0 (adjusted with dilute orthophosphoric acid).

\subsubsection{Linearity and Range}

The linear response of Loperamide Hydrochloride was established by plotting a graph to concentration versus area and determined the correlation coefficient. $20 \mu \mathrm{L}$ of each of the standard solutions of Loperamide Hydrochloride to about 50\%, 80\%, 100\%, 120\% and 150\% (ranging from $0.1-0.3 \mu \mathrm{g} / \mathrm{mL}$ ) of the target concentration were prepared single time and injected each solution three times onto the HPLC system. A graph was plotted by placing concentration $(\mathrm{mg} / \mathrm{mL})$ on $\mathrm{X}$-axis versus area on Y-axis. The correlation coefficient was calculated for principle peaks. From the results slope, intercept, correlation coefficient (r) of the least regression line was calculated.

\subsubsection{Accuracy}

The accuracy of the method was determined for the Loperamide Hydrochloride by spiking the stock solution of Loperamide Hydrochloride in a blank matrix in triplicate at levels 50\%, $100 \%$ and $150 \%$ of the working concentration. Each sample solution was prepared three times at each spiked level and injected onto the HPLC system single time. The \% of recovery of Loperamide Hydrochloride was calculated.

\subsubsection{Specificity}

The specificity of the method was determined by subjecting the active drug to force/stress conditions (such as acid hydrolysis, base hydrolysis, peroxide degradation, thermal degradation, and photolytic degradation). The samples and standards under stress conditions were monitored in order to demonstrate detectable interference due to degraded compounds or any other compounds formed. In order to see the reactivity of inactive placebo with Loperamide Hydrochloride under stress conditions, the placebo mixture (without the actives) was also treated under the same conditions. The resulting mixtures were then analyzed.

\subsubsection{Precision}

(a) System Precision

Successive six injections of $20 \mu \mathrm{L}$ working standard solution (six replicates) were injected into and HPLC column. The peak area and chromatograms obtained were recorded. The $\%$ relative standard deviation was calculated for peak areas of replicates.

(b) Method Precision of System Suitability

$20 \mu \mathrm{L}$ of standard solutions of Loperamide Hydrochloride were injected into HPLC column and chromatograms were recorded. From the data obtained system suitability parameters like theoretical plates, tailing factor, \% RSD and resolution were calculated.

\subsubsection{Robustness}

To prove the reliability of the analytical method during normal usages, some small but deliberate changes (e.g., solution stability, mobile phase stability, flow rate, column temperature, mobile phase 
composition, filter volume validation, sonication time variation) were made in the analytical method. Changes in the chromatographic parameters (i.e., theoretical plates and the tailing factors) were evaluated for the studies.

\section{RESUlT AND DISCUSSION}

\subsection{Linearity and Ranges}

The linearity response for Loperamide Hydrochloride was observed in the concentration range of 0.1$0.3 \mu \mathrm{g} / \mathrm{mL}$ with correlation coefficient, percentage curve fittings found to be well within the acceptance criteria limit. The linearity and regression coefficient value is 0.9999 for the Loperamide Hydrochloride. This proves that the response is linear within the concentration range of $0.1-0.3$ $\mu \mathrm{g} / \mathrm{mL}$ (see figure). These data are summarized in table 1 .

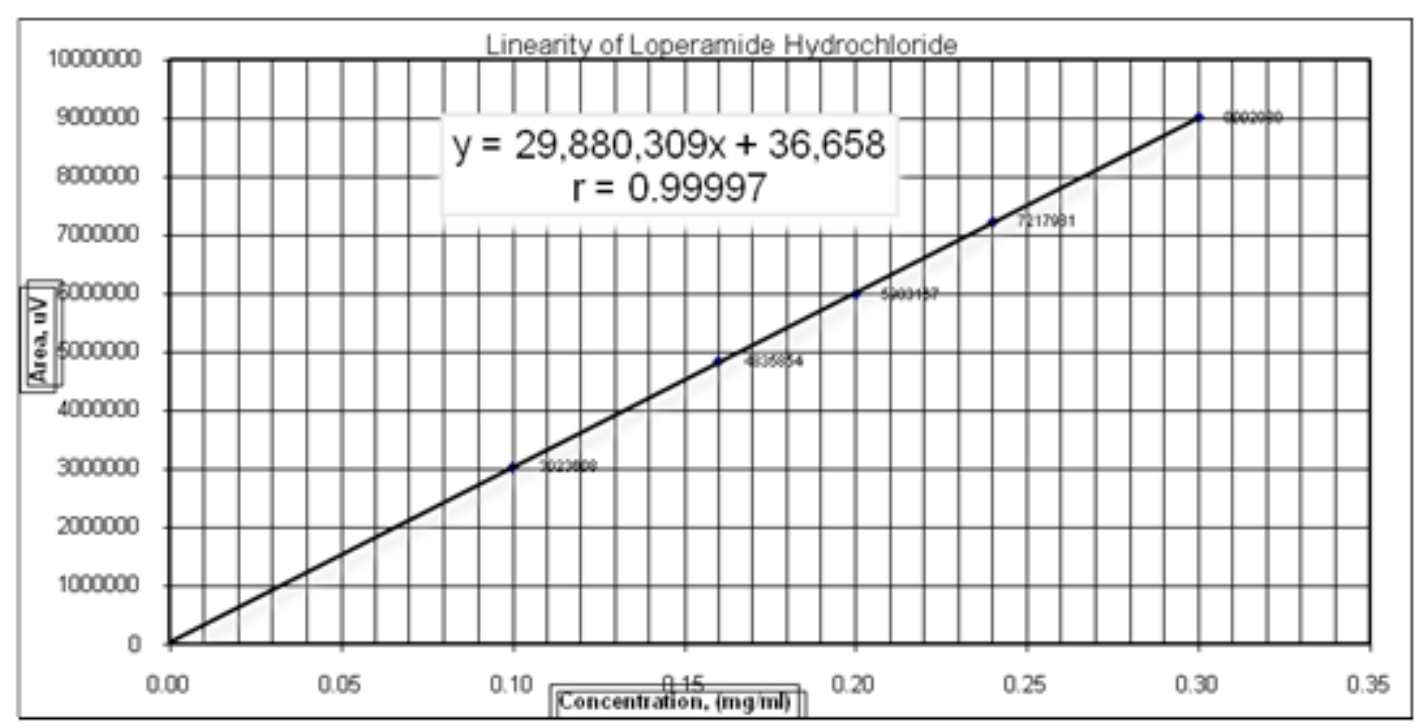

Figure2. Linearity curve for Loperamide Hydrochloride

Table1. Linearity of Loperamide Hydrochloride

\begin{tabular}{|c|c|}
\hline Concentration, $(\mathbf{m g} / \mathbf{m L})$ & Area of Loperamide Hydrochloride peak \\
\hline 0.1000 & 3325969 \\
\hline 0.1600 & 5319439 \\
\hline 0.2000 & 6581484 \\
\hline 0.2400 & 7939779 \\
\hline 0.3000 & 9903288 \\
\hline Slope & 32868340 \\
\hline Y-intercept & 40323 \\
\hline Median (Area) & 6581484 \\
\hline \% Y intercept & 0.61 \\
\hline Correlation coefficient, $r$ & 0.9999 \\
\hline
\end{tabular}

\subsection{Specificity}

Specificity is the ability of the method to accurately measure the analyte responses in the presence of all formulation ingredients. A study was conducted to demonstrate the effective separation of Loperamide Hydrochloride. Also study was intended to ensure the effective separation of degradation peaks of formulation ingredients at the retention time of Loperamide Hydrochloride. Stress studies of the drug's active pharmaceutical ingredients were utilized for the identification of the possible degradation products and for the validation of the suitability-indicating analytical procedures. It is the ability of the analytical method to measure the analyte response in the presence of its degradation products. The samples and standards under stress conditions were monitored in order to demonstrate detectable interference due to degradents or any other compounds formed. In order to see, the reactivity of inactive placebo with Loperamide Hydrochloride under stress conditions, the placebo mixture (without the actives) was also treated under the same conditions. The resulting mixtures were then analyzed. The result obtained from the forced degradation studies is summarized in table 2.

During the forced degradation study, Loperamide Hydrochloride was degraded under acid hydrolysis, base hydrolysis and peroxide degradation. In all cases the peak of Loperamide Hydrochloride is well 
separated from the degradants (resolution- acid hydrolysis: 14.25; base hydrolysis: 5.12; peroxide oxidation: 3.08. But the peak of Loperamide Hydrochloride was found to be pure and no considerable degradation of drug substance was observed in thermal and photolytic degradation. The chromatograms were checked for the appearance of any extra or overlapping peaks. Peak purity of these samples under stressed conditions was verified. The purity of the principle and other chromatographic peaks was found to be satisfactory. The above results reveal that under acid, basic and peroxide condition the degradation for Loperamide Hydrochloride is significant. Purity angle found less than purity threshold for Loperamide Hydrochloride peak. The excipients used in the formulation do not interfere in determination of Loperamide Hydrochloride in Loperamide Hydrochloride Tablets. This study confirmed the stability indicating power of the HPLC method.

Table2. Force Degradation Study results

\begin{tabular}{|c|c|c|c|}
\hline $\begin{array}{c}\text { Treated } \\
\text { condition }\end{array}$ & $\begin{array}{c}\text { Sample } \\
\text { Name }\end{array}$ & $\%$ Assay & Remarks \\
\hline \multirow{2}{*}{$\begin{array}{l}\text { Without } \\
\text { Treatment }\end{array}$} & Placebo & N/A & Not degraded \\
\hline & Sample & 94.27 & $\begin{array}{c}\text { Not degraded } \\
\text { Purity angle (0.25) found less than purity threshold (2.52) for Loperamide } \\
\text { Hydrochloride }\end{array}$ \\
\hline \multirow[t]{3}{*}{ Acid Hydrolysis } & Placebo & N/A & \begin{tabular}{|c|} 
Not degraded \\
\end{tabular} \\
\hline & API & 89.07 & $\begin{array}{c}\text { Loperamide Hydrochloride peak is degraded } \\
\text { Peak is well separated from degradants, resolution: } 3.08 \text { and purity angle } \\
(0.48) \text { found less than purity threshold }(1.25) \text { for Loperamide } \\
\text { Hydrochloride. }\end{array}$ \\
\hline & Sample & 91.25 & $\begin{array}{l}\text { Loperamide Hydrochloride peak is degraded } \\
\text { Peak is well separated from degradants, resolution: } 14.25 \text { and purity angle } \\
\text { (2.51) found less than purity threshold (43.12) for Loperamide } \\
\text { Hydrochloride. }\end{array}$ \\
\hline \multirow[t]{3}{*}{ Base Hydrolysis } & Placebo & N/A & Not degraded \\
\hline & API & 91.02 & $\begin{array}{c}\text { Loperamide Hydrochloride peak is degraded } \\
\text { Peak is well separated from degradants, resolution: } 1.55 \text { and purity angle } \\
(0.41) \text { found less than purity threshold }(8.29) \text { for Loperamide } \\
\text { Hydrochloride. }\end{array}$ \\
\hline & Sample & 93.87 & $\begin{array}{c}\text { Loperamide Hydrochloride peak is degraded } \\
\text { Peak is well separated from degradants, resolution: } 5.12 \text { and purity angle } \\
(3.25) \text { found less than purity threshold (23.19) for Loperamide } \\
\text { Hydrochloride. }\end{array}$ \\
\hline \multirow{3}{*}{$\begin{array}{l}\text { Peroxide } \\
\text { oxidation }\end{array}$} & Placebo & N/A & Not degraded \\
\hline & API & 87.57 & $\begin{array}{l}\text { Loperamide Hydrochloride peak is degraded } \\
\text { Peak is well separated from degradants, resolution: } 3.87 \text { and purity angle } \\
\text { (12.10) found less than purity threshold (47.12) for } \\
\text { Loperamide Hydrochloride. }\end{array}$ \\
\hline & Sample & 91.86 & $\begin{array}{l}\text { Loperamide Hydrochloride peak is degraded } \\
\text { Peak is well separated from degradants, resolution: } 3.08 \text { and purity angle } \\
\text { (11.52) found less than purity threshold (18.08) for } \\
\text { Loperamide Hydrochloride. }\end{array}$ \\
\hline \multirow{3}{*}{$\begin{array}{c}\text { Thermal } \\
\text { Degradation }\end{array}$} & Placebo & N/A & Not degraded \\
\hline & API & 99.01 & $\begin{array}{c}\text { Not degraded } \\
\text { Purity angle (0.02) found less than purity threshold (0.51) for Loperamide } \\
\text { Hydrochloride }\end{array}$ \\
\hline & Sample & 99.25 & $\begin{array}{l}\text { Not degraded } \\
\text { Purity angle (1.71) found less than purity threshold (52.41) for } \\
\text { Loperamide Hydrochloride }\end{array}$ \\
\hline \multirow{3}{*}{$\begin{array}{l}\text { Photolytic } \\
\text { degradation }\end{array}$} & Placebo & N/A & Not degraded \\
\hline & API & 99.01 & $\begin{array}{c}\text { Not Degraded } \\
\text { Purity angle (0.041) found less than purity } \\
\text { threshold }(0.58) \text { for Loperamide Hydrochloride }\end{array}$ \\
\hline & Sample & 97.05 & $\begin{array}{c}\text { Not Degraded } \\
\text { Purity angle (1.15) found less than purity threshold (51.91) for } \\
\text { Loperamide Hydrochloride }\end{array}$ \\
\hline
\end{tabular}




\subsection{Precision}

\subsubsection{System Precision}

The percentage of relative standard deviation (\% RSD) of peak retention time and area for six replicate injections of standard Loperamide Hydrochloride were found to be 0.16 and 0.09 respectively, which are well within the acceptance criteria limit of not more than $2 \%$. The results are described in the following table 3 .

Table3. Results of system precision

\begin{tabular}{|c|c|c|c|c|}
\hline Injection Number & Retention Time & Area & Tailing Factor & Theoretical Plate \\
\hline 01 & 6.89 & 6594370 & 1.62 & 2842 \\
\hline 02 & 6.78 & 6596794 & 1.68 & 2932 \\
\hline 03 & 6.95 & 6600875 & 1.67 & 3233 \\
\hline 04 & 6.77 & 6594418 & 1.68 & 2833 \\
\hline 05 & 6.76 & 6588357 & 1.69 & 2934 \\
\hline 06 & 6.77 & 6585506 & 1.62 & 2837 \\
\hline Average & 6.82 & 6593386 & NA & NA \\
\hline \% RSD & 1.17 & 0.09 & NA & NA \\
\hline
\end{tabular}

\subsubsection{Method Precision}

The percentage of relative standard deviation (\% RSD) of concentration for method precision of six replicate injections of Loperamide Hydrochloride was found to be 0.21 , which is well within the acceptance criteria limit of not more than $2 \%$. The results are described in the following table 4 .

Table4. Sample Precision (Assay)

\begin{tabular}{|c|c|c|c|c|c|c|}
\hline $\begin{array}{l}\text { Sample } \\
\text { Number }\end{array}$ & $\begin{array}{l}\text { Theoretical conc. of } \\
\text { Loperamide } \\
\text { Hydrochloride } \\
(\mathrm{mg} / \mathrm{mL})\end{array}$ & $\begin{array}{c}\text { Determined conc. of } \\
\text { Loperamide } \\
\text { Hydrochloride } \\
(\mathrm{mg} / \mathrm{mL})\end{array}$ & $\begin{array}{c}\% \text { of } \\
\text { Assay }\end{array}$ & $\begin{array}{c}\text { Average } \\
\text { Result (\%) }\end{array}$ & $\begin{array}{l}\text { RSD } \\
(\%)\end{array}$ & $\begin{array}{c}95 \% \\
\text { Confidence } \\
\text { Interval }\end{array}$ \\
\hline 1 & 0.20000 & 0.19776 & 98.88 & \multirow{6}{*}{98.91} & \multirow{6}{*}{0.22} & \multirow{6}{*}{$98.91 \pm 0.16$} \\
\hline 2 & 0.20000 & 0.19714 & 98.57 & & & \\
\hline 3 & 0.20000 & 0.19806 & 99.03 & & & \\
\hline 4 & 0.20000 & 0.19838 & 99.19 & & & \\
\hline 5 & 0.20000 & 0.19778 & 98.89 & & & \\
\hline 6 & 0.20000 & 0.19778 & 98.89 & & & \\
\hline
\end{tabular}

Acceptance Criteria: \% RSD of the result of six Sample preparations should not be more than $2.0 \%$.The relative standard deviation (RSD) of the concentration of Loperamide Hydrochloride was found to be 0.21 (within the acceptable limit of $2 \%$ ).

\subsection{Accuracy}

The accuracy of the assay method was evaluated in triplicate at three concentration levels $50 \%, 100 \%$ and $150 \mu \mathrm{g} / \mathrm{mL}$ in the bulk drug sample. The percentage recovery of Loperamide Hydrochloride in the bulk drug samples ranged from 99.04 to 100.56 respectively. High recovery results obtained from the proposed HPLC assay method indica tes that this method can be used for quantitative routine quality control analysis of pharmaceutical dosage form. The results are shown in the following table 5.

Table5. Accuracy

\begin{tabular}{|c|c|c|c|c|c|}
\hline $\begin{array}{c}\text { Sample } \\
\text { No }\end{array}$ & $\begin{array}{l}\text { Spiked } \\
\text { level } \\
(\%)\end{array}$ & $\begin{array}{l}\text { Theoretical conc. of } \\
\text { Loperamide Hydrochloride } \\
(\mathrm{mg} / \mathrm{ml})\end{array}$ & $\begin{array}{c}\text { Determined conc. of } \\
\text { Loperamide Hydrochloride } \\
(\mathrm{mg} / \mathrm{ml})\end{array}$ & $\begin{array}{c}\% \text { of } \\
\text { Recovery }\end{array}$ & $\begin{array}{c}\text { Mean \& } \\
\% \text { RSD }\end{array}$ \\
\hline 1 & 50 & 0.10020 & 0.10005 & 99.85 & \multirow{3}{*}{$\begin{array}{c}99.66 \\
0.48\end{array}$} \\
\hline 2 & 50 & 0.10020 & 0.10021 & 100.01 & \\
\hline 3 & 50 & 0.10060 & 0.09971 & 99.12 & \\
\hline 4 & 100 & 0.19800 & 0.19802 & 100.01 & \multirow{3}{*}{$\begin{array}{c}99.98 \\
0.45\end{array}$} \\
\hline 5 & 100 & 0.19700 & 0.19781 & 100.41 & \\
\hline 6 & 100 & 0.20000 & 0.19904 & 99.52 & \\
\hline 7 & 150 & 0.29800 & 0.29755 & 99.85 & \multirow{3}{*}{$\begin{array}{c}99.64 \\
0.43\end{array}$} \\
\hline 8 & 150 & 0.30000 & 0.29745 & 99.15 & \\
\hline 9 & 150 & 0.29700 & 0.29676 & 99.92 & \\
\hline \multicolumn{3}{|c|}{ Grand average $(\%)$} & \multicolumn{3}{|c|}{99.76} \\
\hline \multicolumn{3}{|c|}{ Pooled RSD $(\%)$} & \multicolumn{3}{|c|}{0.42} \\
\hline \multicolumn{3}{|c|}{$95 \%$ confidence Interval } & \multicolumn{3}{|c|}{$99.76 \pm 0.35$} \\
\hline
\end{tabular}

Acceptance Criteria: (a) The \% Assay should not be less than 98.0 and should not be more than 102.0. (b) Pooled RSD: NMT 2.0\% 


\subsection{Robustness}

To prove the method developed is robust, some small but deliberate changes were made in the analytical method (e.g., solution stability, mobile phase stability, flow rate, column temperature, mobile phase composition, filter volume validation, sonication time variation etc.) were performed. The results found were described below.

\subsubsection{Test of Robustness for Solution Stability}

For the method developed, the solution stability was studied for both the standard solution and the sample solution after 48 hours preservation at two different temperatures (e.g at 2-8 ${ }^{\circ} \mathrm{C}$ and at room temperature). The percentage of recovery for both the standard as well as sample solution was calculated.

\section{System Suitability}

The system suitability parameters of standard solution were monitored during the course of validation experiment. Freshly prepared standard solution was injected onto the HPLC system and chromatograms were recorded. The results are summarized in table 6 .

The relative standard deviation (RSD) of the Loperamide Hydrochloride peak retention time and area found to be 1.07 and 0.34 respectively (within the acceptable limit of $2 \%$ ). The above results reveal that the system meets the required system suitability.

Table6. System Suitability for the test of robustness for solution stability

\begin{tabular}{|c|c|c|c|c|}
\hline Injection Number & Retention Time & Area & Tailing Factor & Theoretical Plate \\
\hline 01 & 7.128 & 6622445 & 1.77 & 2215 \\
\hline 02 & 7.204 & 6594393 & 1.67 & 2218 \\
\hline 03 & 7.305 & 6632921 & 1.68 & 2235 \\
\hline 04 & 7.109 & 6630046 & 1.65 & 2265 \\
\hline 05 & 7.107 & 667242 & 1.66 & 2241 \\
\hline 06 & 7.202 & 6639430 & 1.65 & 2298 \\
\hline Average & 7.18 & 6627410 & N/A & N/A \\
\hline \% RSD & 1.07 & 0.34 & N/A & N/A \\
\hline
\end{tabular}

Test of Robustness for the Standard Solution Stability

The standard solution preparation for precision was injected onto the HPLC system after 48 hours storage at room temperature and $2-8{ }^{\circ} \mathrm{C}$. The peak response for Loperamide Hydrochloride was recorded. The \% recovery of Loperamide Hydrochloride was calculated. The results are summarized in Table 7.

Table7. Standard solution stability for Loperamide Hydrochloride

\begin{tabular}{|c|c|}
\hline Time Interval & \% Recovery \\
\hline After 48 hours at room temperature & 99.50 \\
\hline After 48 hours at $2-8^{\circ} \mathrm{C}$ & 99.96 \\
\hline
\end{tabular}

Acceptance Criteria: \% Recovery of standard should be in the range of 98.0 to 102.0. The above results reveal that the standard solution is stable up to 48 hours.

\section{Test of Robustness for Sample Solution Stability}

The sample solution preparation for precision was injected onto the HPLC system after 48 hours storage at room temperature and $2-8{ }^{\circ} \mathrm{C}$ and recorded peak response for Loperamide Hydrochloride. The assay of the sample was calculated and compared with precision results. The results are summarized in table 8 .

Table8. Sample solution stability for Loperamide Hydrochloride

\begin{tabular}{|c|c|c|}
\hline Time Interval & \% Assay & Difference from Initial \\
\hline Initial & 98.91 & NA \\
\hline After 48 hours at room temperature & 98.02 & 0.89 \\
\hline After 48 hours at $2-8^{\circ} \mathrm{C}$ & 98.97 & 0.06 \\
\hline
\end{tabular}

Acceptance Criteria: The \% assay result should not differ from initial value by more than 2.0. 


\section{Homayun Kabir et al.}

The percentage of recovery for the standard solution was found to be 99.50 and 99.96 at room temperature and at $2-8{ }^{\circ} \mathrm{C}$ respectively. Similarly the percentage of recovery of the sample solution as soon as it is prepared was found to be at $2-8{ }^{\circ} \mathrm{C}$. But after 48 hours storage at $2-8{ }^{\circ} \mathrm{C}$ and at room temperature, the \% of recovery was found to be 98.97 and 98.02 respectively. So the \% assay does not differ from initial value by more than 2.0 , which meet the acceptance criteria. The above results reveal that the sample solution is stable up to 48 hours.

\subsubsection{Test of Robustness for Mobile Phase Stability}

For the method developed, the mobile phase stability was studied by injecting the mobile phase onto the HPLC column after 48 hours of the preservation. The \% RSD of assay result was calculated.

\section{System Suitability for the Test of Robustness for Mobile Phase Stability}

The system suitability parameters of the standard solution were monitored by recording the chromatograms followed by injecting six replica of the mobile phase onto the HPLC at different time intervals during the course of validation experiment. The results are summarized in table 9.

Table9. System Suitability using mobile phase after 48 hours

\begin{tabular}{|c|c|c|c|c|}
\hline Injection Number & Retention Time & Area & Tailing Factor & Theoretical Plate \\
\hline 01 & 7.16 & 6671661 & 1.73 & 2137 \\
\hline 02 & 7.17 & 6688330 & 1.73 & 2137 \\
\hline 03 & 7.27 & 6679891 & 1.74 & 2238 \\
\hline 04 & 7.18 & 6698825 & 1.71 & 2336 \\
\hline 05 & 7.28 & 6682731 & 1.74 & 2042 \\
\hline 06 & 7.18 & 6676581 & 1.73 & 2138 \\
\hline Average & 7.21 & 6683003 & NA & NA \\
\hline \% RSD & 0.74 & 0.14 & NA & NA \\
\hline
\end{tabular}

The relative standard deviation (RSD) of Loperamide Hydrochloride peak retention time and area found to be 0.74 and 0.14 respectively (within the acceptable limit of $2 \%$ ). The above results reveal that the system meets the required system suitability.

\section{Method Precision for the Test of Robustness for Mobile Phase Stability}

The sample solutions were prepared six times and injected each solution single time. The \% Assay and $\%$ RSD was calculated. The results are summarized in Table-10 to 11

Table10. Sample Precision after storing the mobile phase 48 hours

\begin{tabular}{|c|c|c|c|c|}
\hline Injection Number & Retention Time & Area & Tailing Factor & Theoretical Plate \\
\hline 01 & 7.39 & 6517927 & 1.75 & 2164 \\
\hline 02 & 7.40 & 6495039 & 1.75 & 2271 \\
\hline 03 & 7.40 & 6516963 & 1.75 & 2173 \\
\hline 04 & 7.41 & 6555200 & 1.76 & 2360 \\
\hline 05 & 7.42 & 6537520 & 1.72 & 2162 \\
\hline 06 & 7.43 & 6539311 & 1.75 & 2164 \\
\hline Average & 7.41 & 6526993 & NA & NA \\
\hline \% RSD & 0.20 & 0.33 & NA & NA \\
\hline
\end{tabular}

The $\%$ RSD of retention time and pick area for the six sample preparations were found to be 0.05 and 0.33 . Moreover the average \% of assay and \% RSD for the sample in assay experiment were found to be 99.85 and 0.41 respectively. All these results meet the acceptance criteria. So the above results reveal that the mobile phase can be used up to 48 hours.

Table11. Sample Precision (Assay)

\begin{tabular}{|c|c|c|c|c|c|c|}
\hline $\begin{array}{c}\text { Sample } \\
\text { Number }\end{array}$ & $\begin{array}{l}\text { Theoretical conc. of } \\
\text { Loperamide } \\
\text { Hydrochloride } \\
(\mathrm{mg} / \mathrm{ml})\end{array}$ & $\begin{array}{l}\text { Determined conc. of } \\
\text { Loperamide } \\
\text { Hydrochloride } \\
(\mathrm{mg} / \mathrm{ml})\end{array}$ & $\begin{array}{c}\% \text { of } \\
\text { Assay }\end{array}$ & $\begin{array}{c}\text { Average } \\
\text { Result } \\
(\%)\end{array}$ & $\begin{array}{l}\text { RSD } \\
(\%)\end{array}$ & $\begin{array}{l}\text { Difference } \\
\text { from original } \\
\text { condition }\end{array}$ \\
\hline 1 & 0.20000 & 0.19952 & 99.76 & \multirow{6}{*}{99.48} & \multirow{6}{*}{0.37} & \multirow{6}{*}{0.57} \\
\hline 2 & 0.20000 & 0.19876 & 99.38 & & & \\
\hline 3 & 0.20000 & 0.19882 & 99.41 & & & \\
\hline 4 & 0.20000 & 0.20012 & 100.06 & & & \\
\hline 5 & 0.20000 & 0.19842 & 99.21 & & & \\
\hline 6 & 0.20000 & 0.19814 & 99.07 & & & \\
\hline
\end{tabular}

Acceptance Criteria: (a) \% RSD of the result of six sample preparations should not be more than $2.0 \%$. (b)

The \% assay result should not differ from original condition value by more than 2.0. 


\subsubsection{Test of Robustness for Column Oven Temperature Variation}

At first, the system suitability parameters of standard solution were monitored at two different temperatures, viz. at $23{ }^{\circ} \mathrm{C}$ and at $27{ }^{\circ} \mathrm{C}$ during the course of validation experiment. Then the sample solution preparation for precision was injected onto the HPLC system at these two different temperatures. The \% Assay and \% RSD for Assay was calculated. The results are summarized in table 12-17.

\section{Column Oven Set at $23^{\circ} \mathrm{C}$}

\section{a) System Suitability for the Test of Robustness Keeping Column Oven Temperature at $23^{\circ} \mathrm{C}$}

The system suitability parameters of standard solution were monitored during the course of validation experiment. Freshly prepared six replica of standard solution was injected onto the HPLC system and chromatograms were recorded. The results are summarized in table 12.

Table12. System Suitability test for the test of robustness for column oven temperature maintained at $23{ }^{\circ} \mathrm{C}$

\begin{tabular}{|c|c|c|c|c|}
\hline Injection Number & Retention Time & Area & Tailing Factor & Theoretical Plate \\
\hline 01 & 7.01 & 6647033 & 1.72 & 2027 \\
\hline 02 & 7.01 & 6632415 & 1.73 & 2230 \\
\hline 03 & 7.02 & 6638313 & 1.74 & 2228 \\
\hline 04 & 7.03 & 6620275 & 1.71 & 2336 \\
\hline 05 & 7.01 & 6640137 & 1.73 & 2127 \\
\hline 06 & 7.01 & 6651468 & 1.72 & 2224 \\
\hline Average & 7.02 & 6638273 & NA & NA \\
\hline \% RSD & 0.12 & 0.17 & NA & NA \\
\hline
\end{tabular}

The relative standard deviation (RSD) of the Loperamide Hydrochloride peak retention time and area found to be 1.2 and 0.17 respectively (within the acceptable limit of $2 \%$ ). The above results reveal that the system meets the required system suitability.

\section{b) Method Precision for the Test of Robustness Keeping Column Oven Temperature at $23^{\circ} \mathrm{C}$}

The sample solutions were prepared six times and injected each solution single time. The \% Assay and \% RSD for Assay was calculated. The results are summarized in table 13 to 14

Table13. Sample Precision for the test of robustness for column oven temperature maintained at $23{ }^{\circ} \mathrm{C}$

\begin{tabular}{|c|c|c|c|c|}
\hline Injection Number & Retention Time & Area & Tailing Factor & Theoretical Plate \\
\hline 01 & 7.02 & 6475732 & 1.81 & 2018 \\
\hline 02 & 7.03 & 6436040 & 1.82 & 2017 \\
\hline 03 & 7.05 & 6458500 & 1.83 & 2019 \\
\hline 04 & 7.01 & 6436917 & 1.85 & 2105 \\
\hline 05 & 7.03 & 6433343 & 1.84 & 2156 \\
\hline 06 & 7.05 & 6468385 & 1.83 & 2281 \\
\hline Average & 7.03 & 6451486 & NA & NA \\
\hline \% RSD & 0.23 & 0.29 & NA & NA \\
\hline
\end{tabular}

Table14. Sample Precision (Assay) for the test of robustness for column oven temperature maintained at $23{ }^{\circ} \mathrm{C}$

\begin{tabular}{|c|c|c|c|c|c|c|}
\hline $\begin{array}{l}\text { Sample } \\
\text { Number }\end{array}$ & $\begin{array}{l}\text { Theoretical conc. of } \\
\text { Loperamide } \\
\text { Hydrochloride } \\
(\mathrm{mg} / \mathrm{ml})\end{array}$ & $\begin{array}{l}\text { Determined conc. of } \\
\text { Loperamide } \\
\text { Hydrochloride } \\
(\mathrm{mg} / \mathrm{ml})\end{array}$ & $\begin{array}{c}\% \text { of } \\
\text { Assay }\end{array}$ & $\begin{array}{l}\text { Average } \\
\text { Result } \\
(\%)\end{array}$ & $\begin{array}{l}\text { RSD } \\
(\%)\end{array}$ & $\begin{array}{l}\text { Difference } \\
\text { from original } \\
\text { condition }\end{array}$ \\
\hline 1 & 0.20000 & 0.19782 & 98.91 & \multirow{6}{*}{98.79} & \multirow{6}{*}{0.65} & \multirow{6}{*}{0.12} \\
\hline 2 & 0.20000 & 0.19782 & 98.15 & & & \\
\hline 3 & 0.20000 & 0.19674 & 98.37 & & & \\
\hline 4 & 0.20000 & 0.19656 & 98.28 & & & \\
\hline 5 & 0.20000 & 0.19836 & 99.18 & & & \\
\hline 6 & 0.20000 & 0.19964 & 99.82 & & & \\
\hline
\end{tabular}

Acceptance Criteria: (a) \% RSD of the result of six sample preparations should not be more than $2.0 \%$. (b) The \% assay result should not differ from original condition value by more than 2.0.

The \% RSD of retention time and pick area for the six sample preparations were found to be 0.23 and 0.29 . Moreover the $\%$ RSD for the sample in assay experiment was found to be 0.65 . All these results 


\section{Homayun Kabir et al.}

meet the acceptance criteria. So the above results reveal that the method is well robust at column oven temperature maintained at $23^{\circ} \mathrm{C}$.

Column Oven Set at $27^{\circ} \mathrm{C}$

a) System Suitability for the Test of Robustness Keeping Column Oven Temperature at $27^{\circ} \mathrm{C}$

The system suitability parameters of standard solution were first monitored during the course of validation experiment by setting the column oven temperature at $27^{\circ} \mathrm{C}$. Freshly prepared six replica of standard solution was injected onto the HPLC system and chromatograms were recorded. The results are summarized in table 15 .

Table15. System Suitability test for the test of robustness for column oven temperature maintained at $27^{\circ} \mathrm{C}$

\begin{tabular}{|c|c|c|c|c|}
\hline Injection Number & Retention Time & Area & Tailing Factor & Theoretical Plate \\
\hline 01 & 6.12 & 6676306 & 1.71 & 2206 \\
\hline 02 & 6.23 & 6657355 & 1.73 & 2208 \\
\hline 03 & 6.24 & 6661580 & 1.70 & 2118 \\
\hline 04 & 6.21 & 6655711 & 1.70 & 2116 \\
\hline 05 & 6.22 & 6659387 & 1.71 & 2129 \\
\hline 06 & 6.23 & 6668766 & 1.72 & 2123 \\
\hline Average & 6.21 & 6663184 & NA & NA \\
\hline \% RSD & 0.72 & 0.12 & NA & NA \\
\hline
\end{tabular}

The relative standard deviation (RSD) of the Loperamide Hydrochloride peak retention time and area found to be 0.72 and 0.12 respectively (within the acceptable limit of $2 \%$ ). The above results reveal that the system meets the required system suitability.

\section{b) Method Precision for the Test of Robustness Keeping Column Oven Temperature at $27{ }^{\circ} \mathrm{C}$}

The sample solutions were prepared six times and injected each solution single time onto the HPLC column maintaining the column oven temperature at $27^{\circ} \mathrm{C}$. The $\%$ Assay and \% RSD for Assay was calculated. The results are summarized in table16 to 17 .

Table16. Sample Precision for the test of robustness for column oven temperature maintained at $27^{\circ} \mathrm{C}$

\begin{tabular}{|c|c|c|c|c|}
\hline Injection Number & Retention Time & Area & Tailing Factor & Theoretical Plate \\
\hline 01 & 6.88 & 6477804 & 1.71 & 2412 \\
\hline 02 & 6.88 & 6462360 & 1.72 & 2512 \\
\hline 03 & 6.87 & 6430692 & 1.70 & 2412 \\
\hline 04 & 6.88 & 6427942 & 1.69 & 2412 \\
\hline 05 & 6.88 & 6476171 & 1.71 & 2451 \\
\hline 06 & 6.87 & 6482016 & 1.73 & 2471 \\
\hline Average & 6.88 & 6459497 & NA & NA \\
\hline \% RSD & 0.01 & 0.38 & NA & NA \\
\hline
\end{tabular}

The $\%$ Assay and \% RSD were showed in table 17. The \% RSD of retention time and pick area for the six sample preparations were found to be 0.01 and 0.38 . Moreover the \% RSD for the sample in assay experiment was found to be 0.56 . All these results meet the acceptance criteria. So the above results reveal that the method is well robust at column oven temperature maintained at $27{ }^{\circ} \mathrm{C}$.

Table17. Sample Precision (Assay) for the test of robustness for column oven temperature maintained at $27^{\circ} \mathrm{C}$

\begin{tabular}{|c|c|c|c|c|c|c|}
\hline $\begin{array}{l}\text { Sample } \\
\text { Number }\end{array}$ & $\begin{array}{c}\text { Theoretical conc. of } \\
\text { Loperamide } \\
\text { Hydrochloride } \\
(\mathrm{mg} / \mathrm{ml})\end{array}$ & $\begin{array}{l}\text { Determined conc. of } \\
\text { Loperamide } \\
\text { Hydrochloride } \\
(\mathrm{mg} / \mathrm{ml})\end{array}$ & $\begin{array}{c}\% \text { of } \\
\text { Assay }\end{array}$ & $\begin{array}{c}\text { Average } \\
\text { Result }(\%)\end{array}$ & $\begin{array}{l}\text { RSD } \\
(\%)\end{array}$ & $\begin{array}{l}\text { Difference } \\
\text { from } \\
\text { Original } \\
\text { Condition }\end{array}$ \\
\hline 1 & 0.20000 & 0.19694 & 98.47 & \multirow{6}{*}{98.22} & \multirow{6}{*}{0.56} & \multirow{6}{*}{0.15} \\
\hline 2 & 0.20000 & 0.19696 & 98.48 & & & \\
\hline 3 & 0.20000 & 0.19536 & 97.68 & & & \\
\hline 4 & 0.20000 & 0.19482 & 97.41 & & & \\
\hline 5 & 0.20000 & 0.19710 & 98.55 & & & \\
\hline 6 & 0.20000 & 0.19754 & 98.77 & & & \\
\hline
\end{tabular}

Acceptance Criteria: (a) \% RSD of the result of six sample preparations should not be more than $2.0 \%$. (b) The \% assay result should not differ from original condition value by more than 2.0. 


\subsubsection{Test of Robustness for Flow Rate Variation}

For the method developed, the flow rate of $2 \mathrm{~mL} / \mathrm{min}$ was used. The robustness study was carried out with the small deliberate change to $1.9 \mathrm{~mL} / \mathrm{min}$ and $2.1 \mathrm{~mL} / \mathrm{min}$. At first, the system suitability parameters of standard solution were monitored at two different flow rate $(1.9 \mathrm{~mL} / \mathrm{min}$ and 2.1 $\mathrm{mL} / \mathrm{min}$ ) during the course of validation experiment. Then the sample solution preparation for precision was injected onto the HPLC system at these two different flow rates. The \% Assay and \% RSD for assay was calculated.

\section{Flow Rate at $1.9 \mathrm{~mL} / \mathrm{min}$}

\section{a) System Suitability for the Test of Robustness Keeping Flow Rate at $1.9 \mathrm{~mL} / \mathrm{min}$}

Six replica of standard solution were injected onto the HPLC system keeping the flow rate at 1.9 $\mathrm{ml} / \mathrm{min}$ and chromatograms were recorded. The results are summarized in table 18 .

Table18. System Suitability test for the test of robustness for flow rate of mobile phase at $1.9 \mathrm{~mL} / \mathrm{min}$

\begin{tabular}{|c|c|c|c|c|}
\hline Injection Number & Retention Time & Area & Tailing Factor & Theoretical Plate \\
\hline 01 & 7.12 & 6949087 & 1.75 & 2121 \\
\hline 02 & 7.13 & 6953290 & 1.71 & 2212 \\
\hline 03 & 7.12 & 6968573 & 1.74 & 2121 \\
\hline 04 & 7.12 & 6964169 & 1.74 & 2154 \\
\hline 05 & 7.14 & 6984111 & 1.76 & 2214 \\
\hline 06 & 7.11 & 6986473 & 1.73 & NA \\
\hline Average & 7.12 & 69867617 & NA & NA \\
\hline \% RSD & 0.14 & 0.22 & NA & \\
\hline
\end{tabular}

The relative standard deviation (RSD) of the standard Loperamide Hydrochloride peak retention time and area found to be 0.14 and 0.22 respectively (within the acceptable limit of $2 \%$ ). The above results reveal that the system meets the required system suitability.

\section{b) Method Precision for the Test of Robustness Keeping Flow Rate at $1.9 \mathrm{~mL} / \mathrm{min}$}

The sample solutions were prepared six times and injected each solution single time onto the HPLC column maintaining the flow rate of mobile phase at $1.9 \mathrm{~mL} / \mathrm{min}$. The \% Assay and \% RSD for Assay was calculated. The results are summarized in table 19 to 20 .

Table19. Sample Precision System Suitability test for the test of robustness for flow rate of mobile phase at 1.9 $\mathrm{mL} / \mathrm{min}$

\begin{tabular}{|c|c|c|c|c|}
\hline Injection Number & Retention Time & Area & Tailing Factor & Theoretical Plate \\
\hline 01 & 7.24 & 6949087 & 1.82 & 2215 \\
\hline 02 & 7.24 & 6953290 & 1.81 & 2213 \\
\hline 03 & 7.25 & 6968573 & 1.82 & 2142 \\
\hline 04 & 7.24 & 6964169 & 1.82 & 2204 \\
\hline 05 & 7.23 & 6984111 & 1.81 & 2208 \\
\hline 06 & 7.22 & 6986473 & 1.81 & 2111 \\
\hline Average & 7.24 & 6967617 & NA & NA \\
\hline \% RSD & 0.14 & 0.15 & NA & NA \\
\hline
\end{tabular}

Table20. Sample Precision (Assay) test for the test of robustness for flow rate of mobile phase at $1.9 \mathrm{~mL} / \mathrm{min}$

\begin{tabular}{|c|c|c|c|c|c|c|}
\hline $\begin{array}{l}\text { Sample } \\
\text { Number }\end{array}$ & $\begin{array}{c}\text { Theoretical conc. of } \\
\text { Loperamide } \\
\text { Hydrochloride } \\
(\mathrm{mg} / \mathrm{mL})\end{array}$ & $\begin{array}{l}\text { Determined conc. of } \\
\text { Loperamide } \\
\text { Hydrochloride } \\
(\mathrm{mg} / \mathrm{mL})\end{array}$ & $\begin{array}{c}\% \text { of } \\
\text { Assay }\end{array}$ & $\begin{array}{c}\text { Average } \\
\text { Result } \\
(\%)\end{array}$ & $\begin{array}{l}\text { RSD } \\
(\%)\end{array}$ & $\begin{array}{c}\text { Difference from } \\
\text { Original } \\
\text { Condition }\end{array}$ \\
\hline 1 & 0.20000 & 0.19802 & 99.01 & \multirow{6}{*}{99.08} & \multirow{6}{*}{0.26} & \multirow{6}{*}{0.17} \\
\hline 2 & 0.20000 & 0.19824 & 99.12 & & & \\
\hline 3 & 0.20000 & 0.19962 & 98.81 & & & \\
\hline 4 & 0.20000 & 0.19970 & 98.85 & & & \\
\hline 5 & 0.20000 & 0.19836 & 99.18 & & & \\
\hline 6 & 0.20000 & 0.19904 & 99.52 & & & \\
\hline
\end{tabular}

Acceptance Criteria: (a) \% RSD of the result of six sample preparations should not be more than $2.0 \%$. (b) The \% assay result should not differ from original condition value by more than 2.0. 


\section{Homayun Kabir et al.}

The \% RSD of retention time and pick area for the six sample preparations were found to be 0.14 and 0.15 . Moreover the $\%$ RSD for the sample in assay experiment was found to be 0.26 . All these results meet the acceptance criteria. So the above results reveal that the method is well robust at flow rate of mobile phase at $1.9 \mathrm{~mL} / \mathrm{min}$.

\section{Flow Rate at $2.1 \mathrm{~mL} / \mathrm{min}$}

a) System Suitability for the Test of Robustness Keeping Flow Rate at $2.1 \mathrm{~mL} / \mathrm{min}$

Six replica of standard solution were injected onto the HPLC system maintaining the flow rate 2.1 $\mathrm{ml} / \mathrm{min}$ and chromatograms were recorded. The results are summarized in table 21 .

Table21. System Suitability experiment for the test of robustness for flow rate of mobile phase at $2.1 \mathrm{~mL} / \mathrm{min}$

\begin{tabular}{|c|c|c|c|c|}
\hline Injection Number & Retention Time & Area & Tailing Factor & Theoretical Plate \\
\hline 01 & 6.61 & 6298895 & 1.81 & 2155 \\
\hline 02 & 6.63 & 6312437 & 1.82 & 2154 \\
\hline 03 & 6.62 & 6338825 & 1.81 & 2115 \\
\hline 04 & 6.62 & 6324707 & 1.82 & 2141 \\
\hline 05 & 6.62 & 6324229 & 1.83 & 2185 \\
\hline 06 & 6.63 & 6317487 & 1.81 & 2141 \\
\hline Average & 6.62 & 6319441 & NA & NA \\
\hline \% RSD & 0.11 & 0.21 & NA & NA \\
\hline
\end{tabular}

The relative standard deviation (RSD) of the Loperamide Hydrochloride peak retention time and area found to be 0.11 and 0.21 respectively (within the acceptable limit of $2 \%$ ). The above results reveal that the system meets the required system suitability.

\section{b) Method Precision for the Test of Robustness Keeping Flow Rate at $2.1 \mathrm{~mL} / \mathrm{min}$}

The sample solutions were prepared six times and injected each solution single time. The $\%$ Assay and $\%$ RSD for Assay was calculated. The results are summarized in table 22 to 23.

Table22. Sample Precision test for the test of robustness for flow rate of mobile phase at $2.1 \mathrm{~mL} / \mathrm{min}$

\begin{tabular}{|c|c|c|c|c|}
\hline Injection Number & Retention Time & Area & Tailing Factor & Theoretical Plate \\
\hline 01 & 6.61 & 6152062 & 1.82 & 2283 \\
\hline 02 & 6.62 & 6153726 & 1.81 & 2214 \\
\hline 03 & 6.61 & 6152734 & 1.83 & 2242 \\
\hline 04 & 6.62 & 6104009 & 1.81 & 2241 \\
\hline 05 & 6.61 & 611830 & 1.80 & 2204 \\
\hline 06 & 6.62 & 6152246 & 1.82 & 2214 \\
\hline Average & 6.62 & 6137601 & NA & NA \\
\hline \% RSD & 0.08 & 0.38 & NA & NA \\
\hline
\end{tabular}

Table23. Sample Precision (Assay) test for the test of robustness for flow rate of mobile phase at $1.9 \mathrm{~mL} / \mathrm{min}$

\begin{tabular}{|c|c|c|c|c|c|c|}
\hline $\begin{array}{l}\text { Sample } \\
\text { Number }\end{array}$ & $\begin{array}{c}\text { Theoretical conc. of } \\
\text { Loperamide } \\
\text { Hydrochloride } \\
(\mathrm{mg} / \mathrm{mL})\end{array}$ & $\begin{array}{c}\text { Determined conc. of } \\
\text { Loperamide } \\
\text { Hydrochloride } \\
(\mathrm{mg} / \mathrm{mL})\end{array}$ & $\begin{array}{c}\% \text { of } \\
\text { Assay }\end{array}$ & $\begin{array}{c}\text { Average } \\
\text { Result } \\
(\%)\end{array}$ & $\begin{array}{c}\text { RSD } \\
(\%)\end{array}$ & $\begin{array}{l}\text { Difference } \\
\text { from } \\
\text { Original } \\
\text { Condition }\end{array}$ \\
\hline 1 & 0.20000 & 0.19810 & 99.05 & \multirow{6}{*}{99.09} & \multirow{6}{*}{0.11} & \multirow{6}{*}{0.18} \\
\hline 2 & 0.20000 & 0.19824 & 99.12 & & & \\
\hline 3 & 0.20000 & 0.19830 & 99.15 & & & \\
\hline 4 & 0.20000 & 0.19884 & 99.42 & & & \\
\hline 5 & 0.20000 & 0.19778 & 98.89 & & & \\
\hline 6 & 0.20000 & 0.19786 & 98.93 & & & \\
\hline
\end{tabular}

Acceptance Criteria: (a) \% RSD of the result of six sample preparations should not be more than $2.0 \%$. (b) The \% assay result should not differ from original condition value by more than 2.0.

The $\%$ RSD of retention time and pick area for the six sample preparations were found to be 0.08 and 0.38 . Moreover the \% RSD for the sample in assay experiment was found to be 0.11 . All these results meet the acceptance criteria. So the above results reveal that the method is well robust at flow rate of mobile phase at $2.1 \mathrm{~mL} / \mathrm{min}$. 
Method Validation for Assay of Loperamide Hydrochloride by HPLC in Loperamide Hydrochloride Tablets

\subsubsection{Mobile Phase Composition Variation}

The system suitability parameters of standard solution were monitored at two different mobile phase composition (viz. acetonitrile: buffer: $1 \mathrm{M} \mathrm{NaOH}=380: 620: 0.5$ and acetonitrile: buffer: $1 \mathrm{M} \mathrm{NaOH}=$ 400: 600: 0.5) during the course of validation experiment. The sample solution preparation for precision was injected onto the HPLC system at two different mobile phase composition. The \% Assay and \% RSD for Assay was calculated.The results are summarized in table 24 to 29.

Mobile Phase Composition (Acetonitrile: Buffer: $1 \mathrm{M} \mathrm{NaOH}=380: 620: 0.5$ )

a) System suitability for the test of robustness keeping mobile phase composition (Acetonitrile:

Buffer: $1 M \mathrm{NaOH}=380: 620: 0.5$ )

Standard solution was injected onto the HPLC system and chromatograms were recorded. The results are summarized in table 32 .

Table24. System Suitability experiment for the test of robustness for mobile phase composition (Acetonitrile: Buffer: $1 \mathrm{M} \mathrm{NaOH}=380: 620: 0.5$ )

\begin{tabular}{|c|c|c|c|c|}
\hline Injection Number & Retention Time & Area & Tailing Factor & Theoretical Plate \\
\hline 01 & 8.05 & 6736676 & 1.84 & 2312 \\
\hline 02 & 8.06 & 6637136 & 1.82 & 2315 \\
\hline 03 & 8.05 & 6655822 & 1.84 & 2216 \\
\hline 04 & 8.06 & 6658218 & 1.84 & 2222 \\
\hline 05 & 8.06 & 6663901 & 1.83 & 2228 \\
\hline 06 & 8.05 & 6740638 & 1.81 & 2218 \\
\hline Average & 8.06 & 6682065 & NA & NA \\
\hline RSD & 0.07 & 0.67 & NA & NA \\
\hline
\end{tabular}

The relative standard deviation (RSD) of the Loperamide Hydrochloride peak retention time and area found to be 0.04 and 0.67 respectively (within the acceptable limit of $2 \%$ ). The above results reveal that the system meets the required system suitability.

b) Method Precision for the test of robustness keeping mobile phase composition (Acetonitrile: Buffer: $1 \mathrm{M} \mathrm{NaOH}=380: 620: 0.5$ )

The sample solutions were prepared six times as per protocol- MV-P/FU1-MDV/1015/01 and injected each solution single time. The \% Assay and \% RSD for Assay was calculated. The results are summarized in table 25 to 26.

Table25. Sample Precision experiment for the test of robustness for mobile phase composition (Acetonitrile: Buffer: $1 \mathrm{M} \mathrm{NaOH}=380: 620: 0.5$ )

\begin{tabular}{|c|c|c|c|c|}
\hline Injection Number & Retention Time & Area & Tailing Factor & Theoretical Plate \\
\hline 01 & 8.06 & 6472862 & 1.81 & 2237 \\
\hline 02 & 8.04 & 6449721 & 1.85 & 2341 \\
\hline 03 & 8.04 & 6447791 & 1.82 & 2231 \\
\hline 04 & 8.06 & 6460342 & 1.82 & 2339 \\
\hline 05 & 8.05 & 6481684 & 1.83 & 2235 \\
\hline 06 & 8.04 & 6461176 & 1.83 & 2233 \\
\hline Average & 8.05 & 6462262.58 & NA & NA \\
\hline \% RSD & 0.12 & 0.20 & NA & NA \\
\hline
\end{tabular}

Table26. Sample Precision (Assay) experiment for the test of robustness for mobile phase composition (Acetonitrile: Buffer: $1 \mathrm{M} \mathrm{NaOH}=380: 620: 0.5$ )

\begin{tabular}{|c|c|c|c|c|c|c|}
\hline $\begin{array}{l}\text { Sample } \\
\text { Number }\end{array}$ & $\begin{array}{c}\text { Theoretical conc. of } \\
\text { Loperamide } \\
\text { Hydrochloride } \\
(\mathrm{mg} / \mathrm{mL})\end{array}$ & $\begin{array}{c}\text { Determined conc. of } \\
\text { Loperamide } \\
\text { Hydrochloride } \\
(\mathrm{mg} / \mathrm{mL})\end{array}$ & $\begin{array}{l}\% \text { of } \\
\text { Assay }\end{array}$ & $\begin{array}{c}\text { Average } \\
\text { Result } \\
(\%)\end{array}$ & $\begin{array}{l}\text { RSD } \\
(\%)\end{array}$ & $\begin{array}{l}\text { Difference } \\
\text { from } \\
\text { Original } \\
\text { Condition }\end{array}$ \\
\hline 1 & 0.20000 & 0.19824 & 99.12 & \multirow{6}{*}{98.82} & \multirow{6}{*}{0.30} & \multirow{6}{*}{0.09} \\
\hline 2 & 0.20000 & 0.19820 & 99.01 & & & \\
\hline 3 & 0.20000 & 0.19652 & 98.26 & & & \\
\hline 4 & 0.20000 & 0.19764 & 98.82 & & & \\
\hline 5 & 0.20000 & 0.19710 & 98.55 & & & \\
\hline 6 & 0.20000 & 0.19834 & 99.17 & & & \\
\hline
\end{tabular}

Acceptance Criteria: $(a) \%$ RSD of the result of six sample preparations should not be more than $2.0 \%$. (b) The \% assay result should not differ from original condition value by more than 2.0 


\section{Homayun Kabir et al.}

The above results reveal that the method is well robust.

Mobile Phase Composition (Acetonitrile: Buffer: $1 \mathrm{M} \mathrm{NaOH}=400: 600: 0.5$ )

a) System Precision (Suitability)

Standard solution was injected onto the HPLC system and chromatograms were recorded. The results are summarized in table 27.

Table27. System Suitability experiment for the test of robustness for mobile phase composition of Acetonitrile: Buffer: $1 \mathrm{M} \mathrm{NaOH}=400: 600: 0.5$

\begin{tabular}{|c|c|c|c|c|}
\hline Injection Number & Retention Time & Area & Tailing Factor & Theoretical Plate \\
\hline 01 & 5.72 & 6610097 & 1.79 & 2152 \\
\hline 02 & 5.71 & 6600686 & 1.80 & 2154 \\
\hline 03 & 5.72 & 6604282 & 1.81 & 2214 \\
\hline 04 & 5.73 & 6608331 & 1.82 & 2213 \\
\hline 05 & 5.72 & 6627152 & 1.79 & 2210 \\
\hline 06 & 5.71 & 6609865 & 1.80 & 2205 \\
\hline Average & 5.72 & 6610069 & NA & NA \\
\hline \% RSD & 0.13 & 0.14 & NA & NA \\
\hline
\end{tabular}

The relative standard deviation (\% RSD) of the Loperamide Hydrochloride peak retention time and area found to be 0.08 and 0.14 respectively (within the acceptable limit of $2 \%$ ). The above results reveal that the system meets the required system suitability.

\section{b) Method Precision}

The sample solutions were prepared six times and injected each solution single time. The \% Assay and \% RSD for assay was calculated. The results are summarized in table 27 to 28 .

Table28. Sample Precision experiment for the test of robustness for mobile phase composition of Acetonitrile: Buffer: $1 \mathrm{M} \mathrm{NaOH}=400: 600: 0.5$

\begin{tabular}{|c|c|c|c|c|}
\hline Injection Number & Retention Time & Area & Tailing Factor & Theoretical Plate \\
\hline 01 & 5.71 & 6528794 & 1.81 & 2105 \\
\hline 02 & 5.72 & 6518678 & 1.82 & 2089 \\
\hline 03 & 5.71 & 6514654 & 1.80 & 2081 \\
\hline 04 & 5.72 & 6519539 & 1.81 & 2101 \\
\hline 05 & 5.73 & 6522014 & 1.82 & 2085 \\
\hline 06 & 5.71 & 6533173 & 1.80 & 2014 \\
\hline Average & 5.71 & 6522808.78 & NA & NA \\
\hline \%SD & 0.02 & 0.11 & NA & NA \\
\hline
\end{tabular}

Table29. Sample Precision (Assay) experiment for the test of robustness for mobile phase composition of Acetonitrile: Buffer: $1 \mathrm{M} \mathrm{NaOH}=400: 600: 0.5$

\begin{tabular}{|c|c|c|c|c|c|c|}
\hline $\begin{array}{l}\text { Sample } \\
\text { Number }\end{array}$ & $\begin{array}{c}\text { Theoretical conc. of } \\
\text { Loperamide } \\
\text { Hydrochloride } \\
(\mathrm{mg} / \mathrm{mL})\end{array}$ & $\begin{array}{c}\text { Determined conc. of } \\
\text { Loperamide } \\
\text { Hydrochloride } \\
(\mathrm{mg} / \mathrm{mL})\end{array}$ & $\begin{array}{l}\% \text { of } \\
\text { Assay }\end{array}$ & $\begin{array}{c}\text { Average } \\
\text { Result (\%) }\end{array}$ & $\begin{array}{l}\text { RSD } \\
(\%)\end{array}$ & $\begin{array}{l}\text { Difference } \\
\text { from } \\
\text { Original } \\
\text { Condition }\end{array}$ \\
\hline 1 & 0.20000 & 0.20028 & 100.14 & \multirow{6}{*}{99.60} & \multirow{6}{*}{0.44} & \multirow{6}{*}{0.69} \\
\hline 2 & 0.20000 & 0.19978 & 99.89 & & & \\
\hline 3 & 0.20000 & 0.19816 & 99.08 & & & \\
\hline 4 & 0.20000 & 0.19824 & 99.12 & & & \\
\hline 5 & 0.20000 & 0.19904 & 99.52 & & & \\
\hline 6 & 0.20000 & 0.19972 & $99 . .86$ & & & \\
\hline
\end{tabular}

Acceptance Criteria: (a) \% RSD of the result of six sample preparations should not be more than $2.0 \%$. (b) The \% assay result should not differ from original condition value by more than 2.0.

The above results reveal that the method is well robust.

\subsubsection{Filter Volume Variation}

a) System Suitability

Standard solution was injected onto the HPLC system and chromatograms were recorded. The results are summarized in table 30 . 
Method Validation for Assay of Loperamide Hydrochloride by HPLC in Loperamide Hydrochloride Tablets

Table30. System Suitability

\begin{tabular}{|c|c|c|c|c|}
\hline Injection Number & Retention Time & Area & Tailing Factor & Theoretical Plate \\
\hline 01 & 6.72 & 6594370 & 1.82 & 2042 \\
\hline 02 & 6.73 & 6596794 & 1.83 & 2032 \\
\hline 03 & 6.72 & 6600875 & 1.83 & 2033 \\
\hline 04 & 6.71 & 6594418 & 1.83 & 2033 \\
\hline 05 & 6.71 & 6588357 & 1.83 & 2034 \\
\hline 06 & 6.72 & 6585506 & 1.84 & 2037 \\
\hline Average & 6593386.43 & 6593386.43 & NA & NA \\
\hline \% RSD & 0.11 & 0.09 & NA & NA \\
\hline
\end{tabular}

The relative standard deviation (RSD) of the Loperamide Hydrochloride peak retention time and area found to be 0.11 and 0.09 respectively (within the acceptable limit of $2 \%$ ). The above results reveal that the system meets the required system suitability.

b) Filter Volume Variation Study

Filter volume variation study was conducted, considering without filter, $5 \mathrm{~mL}, 10 \mathrm{~mL}, 15 \mathrm{~mL}$ and 20 $\mathrm{mL}$ solution. The results are summarized in table 31.

Table31. Sample solution-Filter volume variation

\begin{tabular}{|c|c|c|c|c|}
\hline Flush Volume & $\begin{array}{l}\text { Theoretical conc. of } \\
\text { Loperamide } \\
\text { Hydrochloride } \\
(\mathrm{mg} / \mathrm{ml})\end{array}$ & $\begin{array}{l}\text { Determined conc. of } \\
\text { Loperamide } \\
\text { Hydrochloride } \\
(\mathrm{mg} / \mathrm{ml})\end{array}$ & $\%$ of Assay & $\begin{array}{l}\text { Difference from } \\
\text { Original } \\
\text { Condition }\end{array}$ \\
\hline As per method & 0.20000 & 0.19662 & $\begin{array}{l}\text { 98.31(Precision } \\
\text { sample-1) }\end{array}$ & NA \\
\hline $5 \mathrm{ml}$ & 0.20000 & 0.19670 & 98.35 & 0.04 \\
\hline $10 \mathrm{ml}$ & 0.20000 & 0.19642 & 98.21 & 0.10 \\
\hline $15 \mathrm{ml}$ & 0.20000 & 0.19842 & 99.21 & 0.10 \\
\hline $20 \mathrm{ml}$ & 0.20000 & 0.19660 & 98.30 & 0.01 \\
\hline
\end{tabular}

Acceptance Criteria: The \% assay result should not differ from original condition value by more than 2.0.

The above results reveal that the method is well precise and robust.

\subsubsection{Sonication with Time Variation}

\section{a) System Suitability}

Standard solution was injected onto the HPLC system and chromatograms were recorded. The results are summarized in table 32 .

Table32. System Suitability

\begin{tabular}{|c|c|c|c|c|}
\hline Injection Number & Retention Time & Area & Tailing Factor & Theoretical Plate \\
\hline 01 & 6.72 & 6594370 & 1.75 & 2214 \\
\hline 02 & 6.71 & 6596794 & 1.76 & 2189 \\
\hline 03 & 6.72 & 6600875 & 1.75 & 2145 \\
\hline 04 & 6.73 & 6594418 & 1.76 & 2198 \\
\hline 05 & 6.72 & 6588357 & 1.71 & 2178 \\
\hline 06 & 6.72 & 6585506 & 1.72 & 2204 \\
\hline Average & 7.72 & 6593386 & NA & NA \\
\hline \%SD & 0.09 & 0.09 & NA & NA \\
\hline
\end{tabular}

The relative standard deviation (RSD) of the Loperamide Hydrochloride peak retention time and area found to be 0.09 and 0.09 respectively (within the acceptable limit of $2 \%$ ). The above results reveal that the system meets the required system suitability.

\section{b) Sonication Time Variation Study}

To check the effectiveness of Sonication time variations Sonication time such as 2, 5, 10 and 20 minutes was considered for standard and sample solutions preparation for 10,20 and 30 minutes. The 
$\%$ of Assay of Loperamide Hydrochloride in Loperamide Hydrochloride tablets was calculated. The results are summarized in table 32 to 33 .

Table33. Standard solution-Sonication time variation

\begin{tabular}{|c|c|c|c|}
\hline $\begin{array}{c}\text { Sonication } \\
\text { Time }\end{array}$ & $\begin{array}{c}\text { Theoretical conc. of Loperamide } \\
\text { Hydrochloride }(\mathrm{mg} / \mathrm{ml})\end{array}$ & $\begin{array}{c}\text { Determined conc. of Loperamide } \\
\text { Hydrochloride }(\mathrm{mg} / \mathrm{ml})\end{array}$ & \% of Recovery \\
\hline $2 \mathrm{~min}$ & 0.20000 & 0.1997 & 99.85 \\
\hline $5 \mathrm{~min}$ & 0.20000 & 0.2003 & 100.14 \\
\hline $10 \mathrm{~min}$ & 0.20000 & 0.2008 & 100.39 \\
\hline $20 \mathrm{~min}$ & 0.20000 & 0.1999 & 99.97 \\
\hline
\end{tabular}

Table34. Sample solution-Sonication time variation

\begin{tabular}{|c|c|c|c|c|}
\hline $\begin{array}{c}\text { Sample } \\
\text { Number }\end{array}$ & $\begin{array}{c}\text { Theoritical conc. of } \\
\text { Loperamide Hydrochloride } \\
(\mathrm{mg} / \mathrm{ml})\end{array}$ & $\begin{array}{c}\text { Determined conc. of } \\
\text { Loperamide Hydrochloride } \\
(\mathrm{mg} / \mathrm{ml})\end{array}$ & $\begin{array}{c}\text { \% of Assay } \\
\text { Difference from } \\
\text { Original } \\
\text { Condition }\end{array}$ \\
\hline 1 & 0.20000 & 0.19970 & 99.85 & 1.10 \\
\hline 2 & 0.20000 & 0.19974 & 99.87 & 1.12 \\
\hline 3 & 0.20000 & 0.19982 & 99.91 & 1.16 \\
\hline
\end{tabular}

Acceptance Criteria: (a) \% Recovery of standard should be in between 98.0 to 102.0 (b) the \% assay of sample should not differ from original condition value by more than 2.0.

The above results reveal that the method is well precise and robust.

\section{Conclusion}

The isocratic HPLC method validated for determination of Loperamide Hydrochloride in Loperamide Hydrochloride Tablets is precise, accurate, linear, robust and specific. Satisfactory results were obtained from validation of the method. The method is stability indicating and can be used for routine analysis and to check the stability sample.

\section{REFERENCES}

[1] US National Cancer Institute, Drug Dictionary.

[2] The British Pharmacopoeia, Published by the Stationery office on behalf of the Medicines \& Healthcare Products Regulatory Agency (MHRA), London, 2007, 2, 1318.

[3] Lavrijsen K.D., Van D., Van H.J., Hendricks J., Monbaliu J., Woestenborghs R., Meuldermans, W. and Heykants, J., Reduction of the prodrug loperamide oxide to its active drug loperamide in the gut of rats, dogs, and humans. J. Pharmacol. Exp. Ther. 1995, 23(3), 354-362.

[4] Litovitz T., Clancy C., Korberly B., Temple A. R., Mann K. V., Surveillance of Loperamide ingestions: an analysis of 216 poison center reports. J. Clin. Toxicol, 35, 11-19. (1997).

[5] Hanauer S. B., The role of loperamide in gastrointestinal disorders. Reviews in Gastroenterological Disorders, 8(1), 15-20, (2008).

[6] De Haven H. D., Cortes B. L., Cassel J.A., Daubert J. D., De Haven R.N., Mansson E., Nagasaka H., Yu G., and Yaksh T., J. Pharmacol. Exp. Ther., 289, 494, (1999).

[7] Pandita R., Rana A., Seth N. and Bala R., Introduction and General Overview of Pharamaceutical Process Validation: A Review. IRJP, 3(6), 60-64, (2012).

[8] Balan P., Nimila I., Carolin, Chundi, I., Sasirekha M. R., Vanaja R. and Rajasekar S. A. Validated RP-HPLC Method for Estimation of Drotaverine $\mathrm{HCl}$ in Pharmaceutical Tablet Dosage Form, Internationjal Journal of Pharmacy \& Pharmaceutical Sciences, 3(4), 77-89 (2011).

[9] Madhu M., Sreeram V., Nagendra kumar A.V.D. and Reddy T. V., Validated RP-HPLC Method for the Determination of Loperamide Hydrochloride in Bulk and Pharmaceutical Formulation, Asian Journal of Biochemical and Pharmaceutical Research, 3(4), 102-111, (2014).

[10] Poornima K. and Channabasavara K.P., Simultaneous Estimation of Loperamide Hydrochloride and Tinidazole in Bulk and Formulations by Reverse Phase High-Performance Liquid Chromatograpy, International Journal of Pharmacy and Pharmaceutical Science, 9(8), 173-177, (2016). 
[11] Ivana S.M., Goran N.S., Ivan S.M., and Valentina M.D., Quantitative analysis of Loperamide Hydrochloride in the presence its acid degradation products, Hem. Ind., 63(1), 39-46, (2009).

[12] The European Agency for the Evaluation of Medicinal Products. ICH Topic Q2B Note for Guideline on Validation of Analytical Procedures: Methodology GPMP/ICH/281, 95, (1996).

Citation: H. Kabir et al., "Method Validation for Assay of Loperamide Hydrochloride by HPLC in Loperamide Hydrochloride Tablets", International Journal of Advanced Research in Chemical Science (IJARCS), vol. 4, no. 4, p. 17, 2017, http://dx.doi.org/10.20431/2349-0403.0404002

Copyright: (C) 2017 Authors. This is an open-access article distributed under the terms of the Creative Commons Attribution License, which permits unrestricted use, distribution, and reproduction in any medium, provided the original author and source are credited. 